\title{
Mathematical model for prediction of colour in the aging of waterproofed porous face ceramic
}

\section{Modelo matemático de predicción del color en el envejecimiento de la cerámica porosa cara vista hidrofugada}

Jesús Ángel Coronado Martín (Main and Corresponding Author)

Carrera de Artes Plásticas, Facultad de Educación, Ciencia y Tecnología (FECYT)

Universidad Técnica del Norte

Avenida 17 de julio, 5-21, CP 100105, Ibarra (Ecuador)

jcoronado@utn.edu.ec

\section{Antonio Rodríguez Rodríguez}

Departamento de Construcción y Tecnología Arquitectónicas. Escuela Técnica Superior de Arquitectura

Universidad Politécnica de Madrid

Av. Juan de Herrera, 4, 28040 Madrid (Spain)

antonio.rodriguez.rodriguez@upm.es

\section{Alfonso García Santos}

Departamento de Construcción y Tecnología Arquitectónicas. Escuela Técnica Superior de Arquitectura Universidad Politécnica de Madrid

Av. Juan de Herrera, 4, 28040 Madrid (Spain)

alfonso.garciasantos@upm.es

Manuscript Code: 891

Date of Acceptance/Reception: 27.07.2018/14.03.2017

DOI: 10.7764/RDLC.17.2.222

\begin{abstract}
This article studies the effect produced by the natural aging process in the chromatic variation on the porous face ceramic treated with water repellents, theoretically colourless, and selected according to their chemical composition. The pottery is waterproofed with each product, leaving it to age in a natural environment for twelve months, and quantifying in each month the histogram values (RGB colour space) and analysing the chromatic variation produced. In the aging process there is a general trend for all products to the loss of red and the gaining of blue, modifying its hue to tonalities which are called "cold", there is a linear relationship in each of the months of the tested materials between the initial colour and the waterproofed ceramic with each of the applied products, being possible the prediction of the final colour to be acquired in each month, depending on the applied waterproofing product.
\end{abstract}

Key words: Ceramic, colour, histogram, water repellents, aging.

Resumen

Se estudia el efecto que produce el envejecimiento natural en la variación cromática de la cerámica porosa cara vista tratada con hidrofugantes, teóricamente incoloros, seleccionados en función de su composición química. La cerámica es hidrofugada con cada producto, dejándola envejecer en ambiente natural durante doce meses, cuantificando cada mes los valores de histograma (espacio de color RGB) y analizando la variación cromática producida. En el proceso de envejecimiento existe una tendencia generalizada en todos los productos a la pérdida del color rojo y ganancia del azul, modificando su tonalidad a los tonos llamados "fríos", existiendo una relación lineal, en cada uno de los meses ensayados, entre el color inicial y final de la cerámica hidrofugada con cada uno de los productos aplicados, pudiendo predecir el color final, que va a adquirir en cada uno de los meses, en función del producto hidrofugante aplicado.

Palabras clave: Cerámica, color, histograma, hidrofugantes, envejecimiento.

Introduction

The deterioration of building materials on historical and current buildings due to environmental aggression is becoming more frequent (Kühnel, 2002). Interventions in architectural heritage are intended to stop the deterioration of materials and propose solutions of conservation so these materials could withstand the alteration processes over a reasonable period of time (Esbert, Montoto, \& Ordaz, 1991).

Due to the alterations suffered by stone and ceramic materials, the use of consolidating products and / or water repellents in interventions oriented to their conservation is necessary. The fundamental action of water repellents is to repel the water which comes into contact with the surface protecting the material from its penetration, and the 
aggressive influence of atmospheric pollution (Esbert \& Sánchez, 1995). The treatment with water repellents is performed by filling the capillary pores of the ceramic material decreasing the suction capacity of capillary water (Fort, 2011).

When a waterproofing treatment is applied, a number of characteristics must be demanded from the used products, such as to reasonably penetrate into the ceramic material, prevent moisture entry, but allowing the breathing of the base material, meaning that it has to be permeable to water vapour, protecting the material from the action of atmospheric pollutants but avoiding changes in neither colour nor appearance of the material on which it is applied (Amoroso \& Fassina, 1985). The variation of certain parameters related to the colour of the material shows a more or less important aesthetic change therefore the use of colorimetry has a relevant application in the field of conservation of architectural heritage, due to its non-destructive nature and potential use as a tool capable of quantifying the colour variation of a building material on which has been applied a surface treatment (Cultrone, De la Torre, Sebastián, \& Cazalla, 2003).

In most cases, at the moment of applying water-repellent products, no variations are observed in the colour of the treated porous ceramic, but over time, depending on the product composition and solar radiation exposure, the material may significantly change its chromaticity and luminosity (García Pascua, Sánchez de Rojas, \& Frías, 1999).

The water repellents applied on granitic rocks, deteriorate when are exposed to ultraviolet light, with slight chromatic variations that are hardly visible in plain sight. This deterioration would involve a tendency of the colour of the samples to the original value of the untreated rocks. However, this does not happen, denoting that the products deterioration results in a residue which eventually might lead to noticeable changes in the colour of the rocks (Rivas, Silva, \& Prieto, 1998).

There is a study on the chromatic variation which occurs on the wood surface when varnishes of different compositions are applied, at the time of their application and within an aging time of five years, concluding that there is a mathematical model to predict the colour of varnished wood, both in its application and aging (Rodríguez, 2012).

Recent studies show that after applying water repellent products, theoretically colourless, on the porous face ceramic, they produce a chromatic variation in the base material at a greater or lesser degree, depending on the product composition and the colour of the base material (Coronado \& García, 2011). There are no current studies that quantify the chromatic variation that occurs on the porous face ceramic when treated with water repellent products, theoretically colourless, over time, quantifying only the colour variation of the ceramic at the moment of the application of the product.

This article analyses the chromatic variation which is produced on the porous ceramic used in exterior walls with exposed façade by applying different theoretically colourless water repellent products, which are classified according to their composition, in order to quantify the colour variation caused by the aging of the treatment under ambient conditions, in order to study whether there is a mathematical model for prediction of colours for aging in ceramics.

The RGB colour space is used for colour quantification, based on the primary colours which are red (R), green (G) and blue (B), performing the digital colour measurement through image histograms. The RGB colour space is recommended when compared with other colour spaces (CIELAB and HSV), for mineral identification (Akhan, Yilmaz \& Kansun, 2010) and it is shown to be a valid colour space to obtain colour quantifications in relative value with respect to a base measurement (Coronado, 2012), thereby generating a very fast tool to use in order to establish a systematization in the applied methodology to quantify chromatic variations in the ceramic materials.

There is research where this model is applied, quantifying surface color variations in relative value with the RGB color space. Chromatic variations are studied with the application of antigraffiti protective treatments on ceramic support (García \& Conci, 2005) and on cement mortar (Sarabia \& García, 2016). Coronado and García (2014) apply the model to identify the water repellent product that minor variation produces in the porous ceramic support used in face facades.

As for the base material, six classified models of ceramic are chosen according to their manufacturing process: manual, pressed and extruded. Each water-repellent product, is chosen according to its composition, and it is applied to each porous ceramic model, quantifying the chromatic variation produced by each product at being applied and over time, obtaining monthly data about the colour during one year. 


\section{Porous face ceramic}

The selection of the porous face ceramic is performed according to the type of its manufacturing: manual, pressed and extruded, taking two models of each type of ceramic. From each model are taken six samples in order to perform the test, characterizing all ceramic selected by calculating their absorption coefficient according to UNE 67027-84 and classifying each ceramic by its initial colour (Coronado \& García, 2014). The values obtained from each ceramic model, classified according to their manufacturing process are shown in Table 1.

\begin{tabular}{|c|c|c|c|c|c|c|}
\hline & \multicolumn{6}{|c|}{ Type of manufacturing of the ceramic } \\
\hline & \multicolumn{2}{|c|}{ Manual } & \multicolumn{2}{|c|}{ Pressed } & \multicolumn{2}{|c|}{ Extruded } \\
\hline & Ceramic 1 & Ceramic 2 & Ceramic 3 & Ceramic 4 & Ceramic 5 & Ceramic 6 \\
\hline Coefficient of & 16.67 & 16.86 & 12.97 & 12.14 & 7.67 & 15.65 \\
\hline $\begin{array}{l}\text { Absorption Ca } \\
\text { (\%) }\end{array}$ & & & & & & \\
\hline $\begin{array}{l}\text { Classification of } \\
\text { colour }\end{array}$ & Brown & Red & Ochre & Red & Red & Ochre \\
\hline
\end{tabular}

\section{Water repellent products}

Water repellent products are divided into two large groups: organic and organic-silicic (Fort, 2007). The chosen products for this research are organic-silicic, as these are the most common used on the porous face ceramic materials, classifying them in: mono-component and bi-component. The water repellent products are chosen according to their composition. The mono-component are: $\mathrm{H} 1$ product of siliconate component, $\mathrm{H} 2$ silanes, $\mathrm{H} 3$ siloxanes oligomeric, $\mathrm{H} 4$ polymeric siloxanes and $\mathrm{H} 5$ fluorinated resin. The $\mathrm{H} 6$ product is of composition silanes / siloxanes, classified as bi-component (Coronado, 2012).

The methodology is based on colorimetric assay (Coronado \& García, 2011; Coronado, 2012; Coronado \& García, 2014; Coronado \& García, 2017) where the parameters of the initial and final colour are obtained at the moment of waterproofing it in a monthly basis during a year in order to see the chromatic variation produced by its aging in ambient conditions. The aging process is simultaneously performed with the different products on all the waterproofed ceramics, so the ambient conditions would equally affect the ceramics, with the aging process beginning in April.

From each chosen ceramic model is waterproofed in laboratory ambient conditions applying the product on half of the face ceramic with a brush until the support is saturated (as recommended by the manufacturers) (Wacker-Chemie, 1973), leaving the other half untreated. The drying time of the waterproofed samples is minimum 24 hours (the recommended time by the manufacturers for the water repellent to be completely dry) (Coronado \& García, 2014; Coronado \& García, 2017). Once the waterproofed ceramic dries, they are exposed to external environmental conditions in Madrid, so that the face of the ceramic remains facing south.

The colour data of the waterproofed ceramic are monthly obtained using a 4.0 megapixel digital camera placed on a table of photo reproduction, positioning the camera lens $40 \mathrm{~cm}$ away from the face of the ceramic. The ceramic is illuminated with four $75 \mathrm{~W}$ lamps, obtaining at the base of the table of photo reproduction, an illuminance value of 760 lux. The waterproofed ceramic is placed on the table of photo reproduction with the face in front of the camera, the same which is triggered by remote control. The result is an image where the sample is fully observed. With a computer program a central part of the waterproofed zone and a central zone of non-waterproofed area are cut, being these last images the analysed ones (Coronado \& García, 2011).

The colour quantification is performed in the RGB colour space, based on the primary colours red (R), green (G) and blue (B), performing a digital colour measurement using image histograms. Image histograms consist of a 256 columns bar graph which represent the number of pixels of the image for each value of lightness, from black (0) to white (255). On the horizontal axis, different luminosities are divided into 256 columns from black (left) to white (right). The height 
of each of the columns determines the number of pixels existing for each of the lightness values, indicating the average (average luminosity value of the group of pixels). The images of both the untreated area (initial colour) and the waterproofed area (final colour) are analysed using image histograms, obtaining measurable data regarding red, green, blue and luminosity.

Data collection is performed monthly, obtaining six photographs of each of the analysed waterproofed ceramic, being analysed and obtaining from each one, their histogram values, being the representative value, the arithmetic mean of the obtained values from green, red, blue and luminosity, in each photograph (Coronado, 2012). Every month the red, green, blue histogram values, and luminosity of both: the untreated ceramics (initial colour), as from the waterproofed ceramics with each one of the products (final colour) are obtained.

Results

The results obtained in Figures 1, 2, 3, 4, 5 and 6, are graphically presented here can be observed the monthly values of the tests on red, green, blue and luminosity of each one of the ceramics.

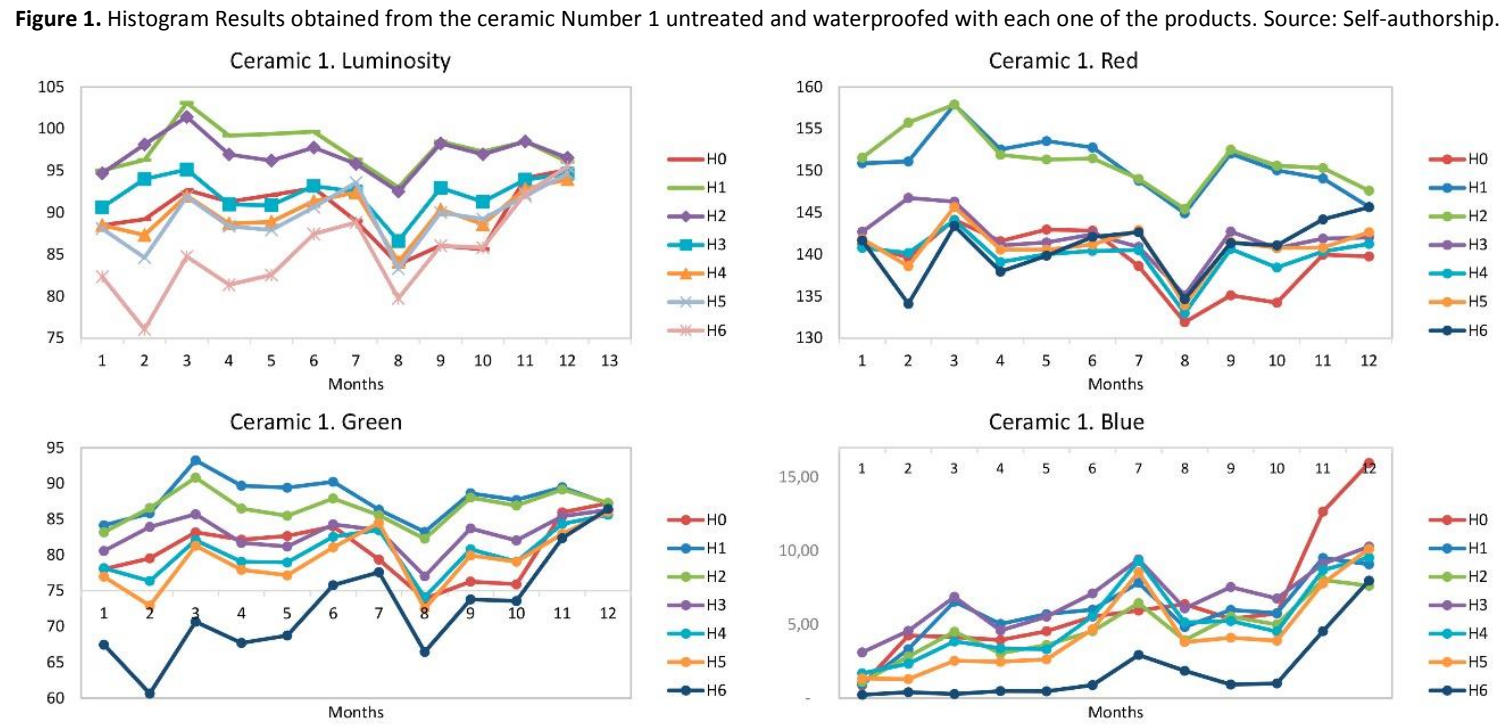

Figure 2. Histogram Results obtained from the ceramic Number 2 untreated and waterproofed with each one of the products. Source: Self-authorship.
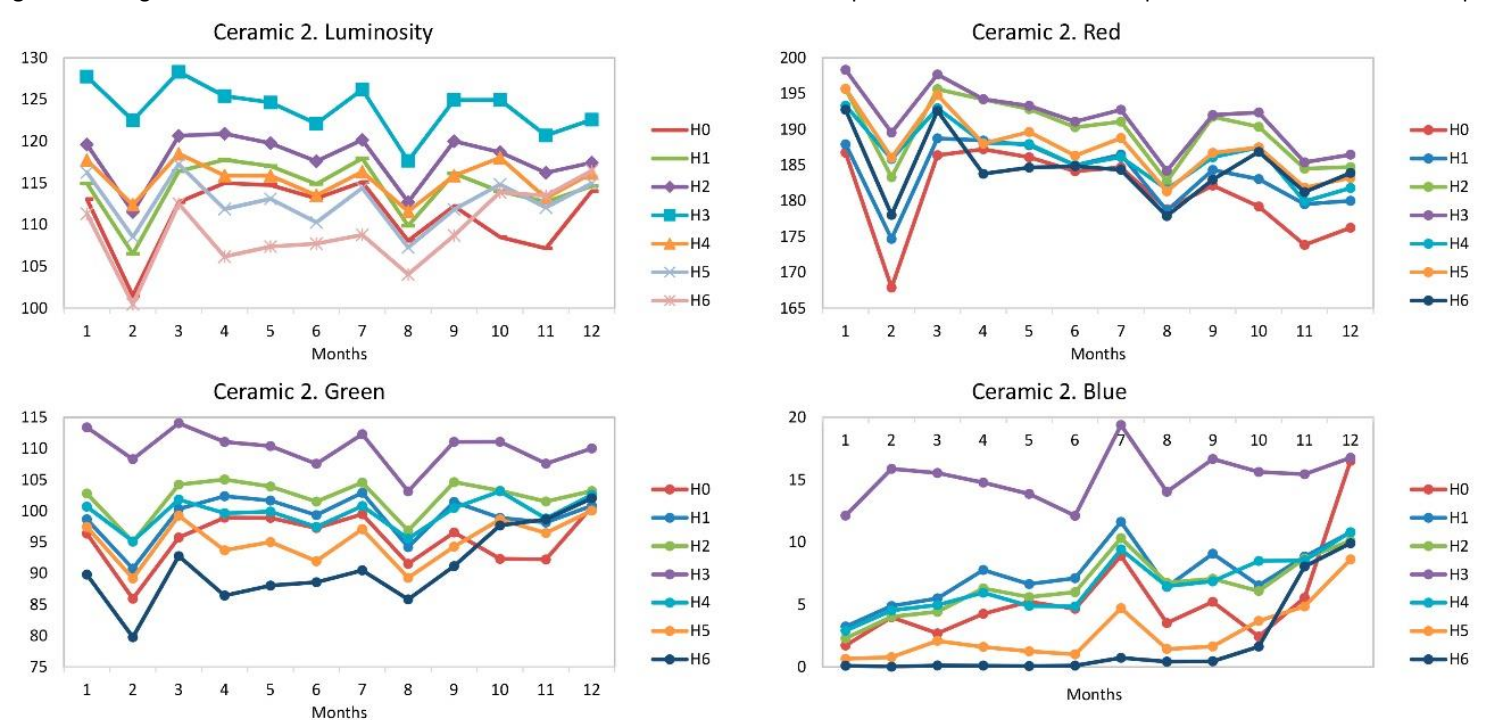
Figure 3. Histogram Results obtained from the ceramic Number 3 untreated and waterproofed with each one of the products. Source: Self-authorship.

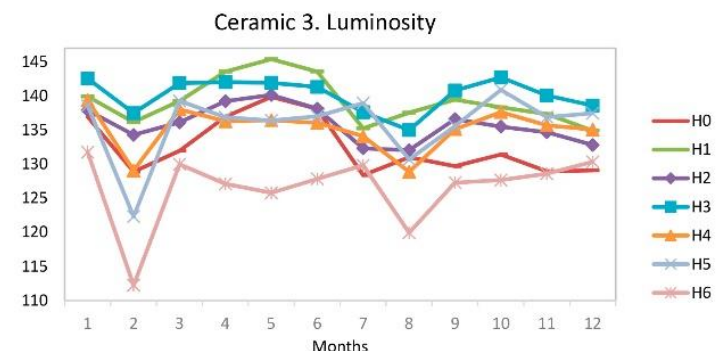
Ceramic 3. Red
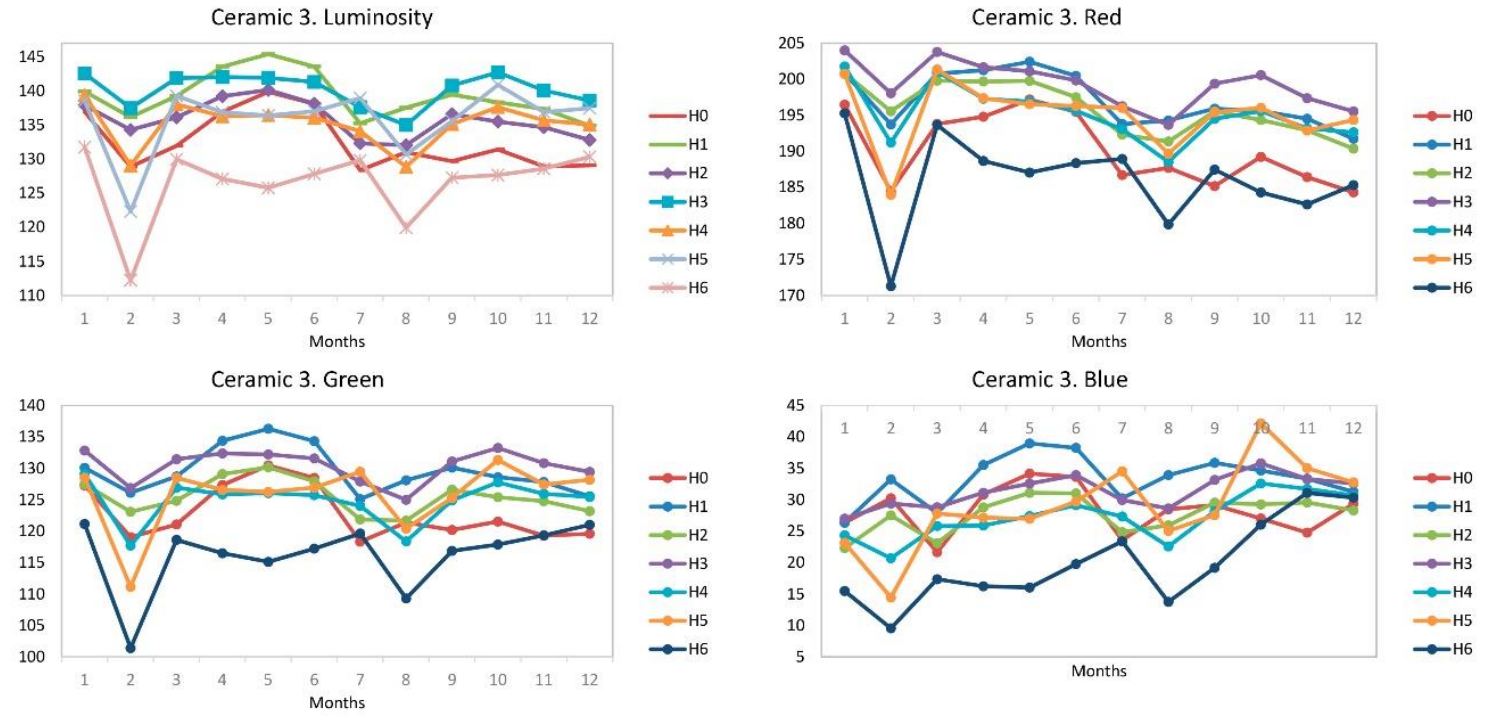

Figure 4. Histogram Results obtained from the ceramic Number 4 untreated and waterproofed with each one of the products. Source: Self-authorship.
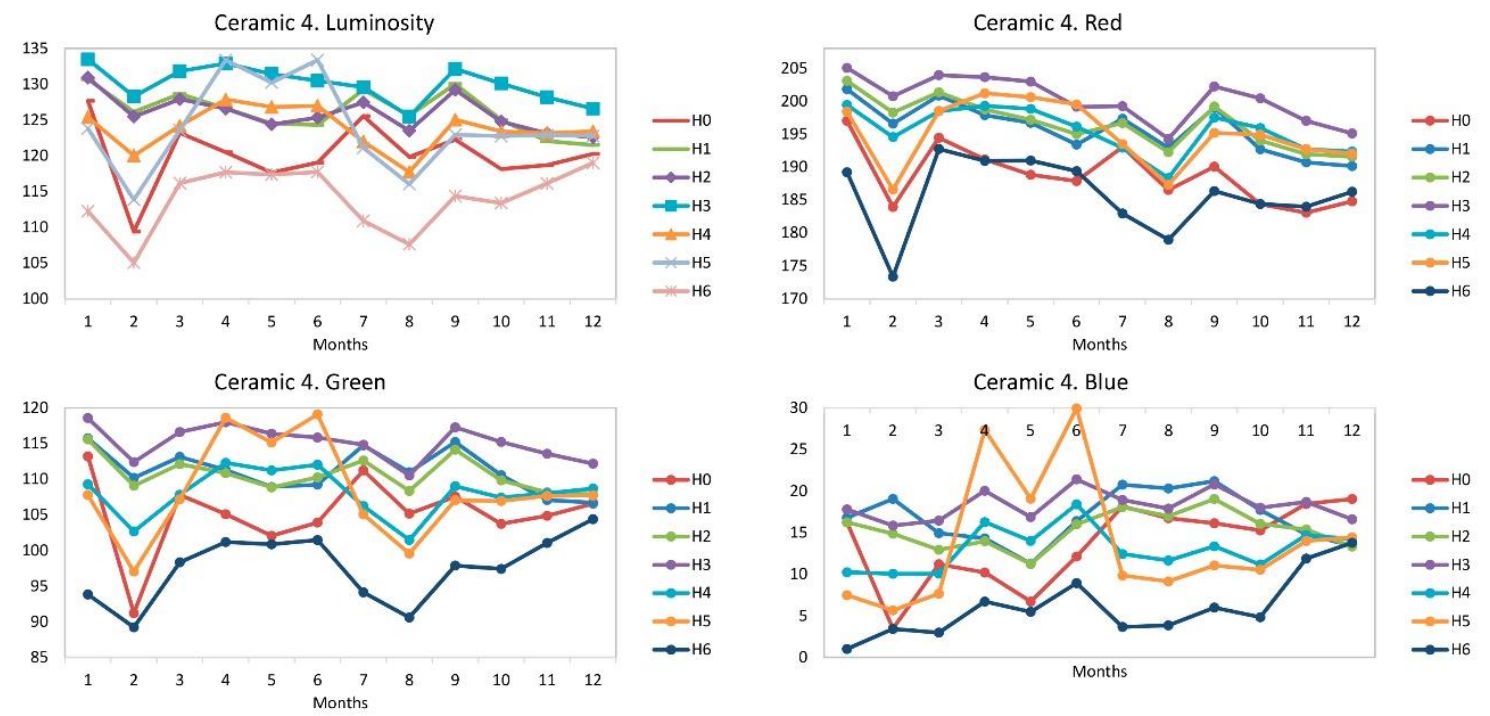

Figure 5. Histogram Results obtained from the ceramic Number 5 untreated and waterproofed with each one of the products. Source: Self-authorship.
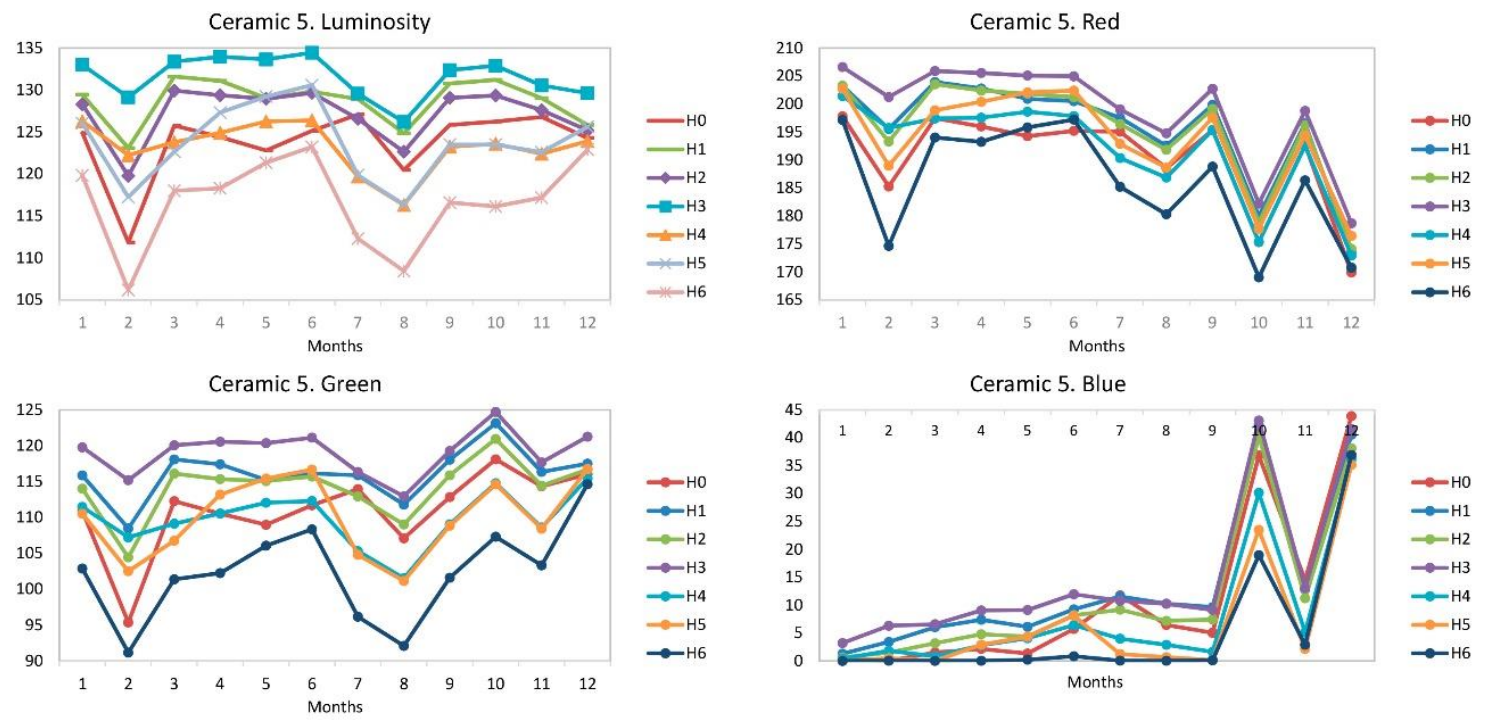
Figure 6. Histogram Results obtained from the ceramic Number 6 untreated and waterproofed with each one of the products. Source: Self-authorship.
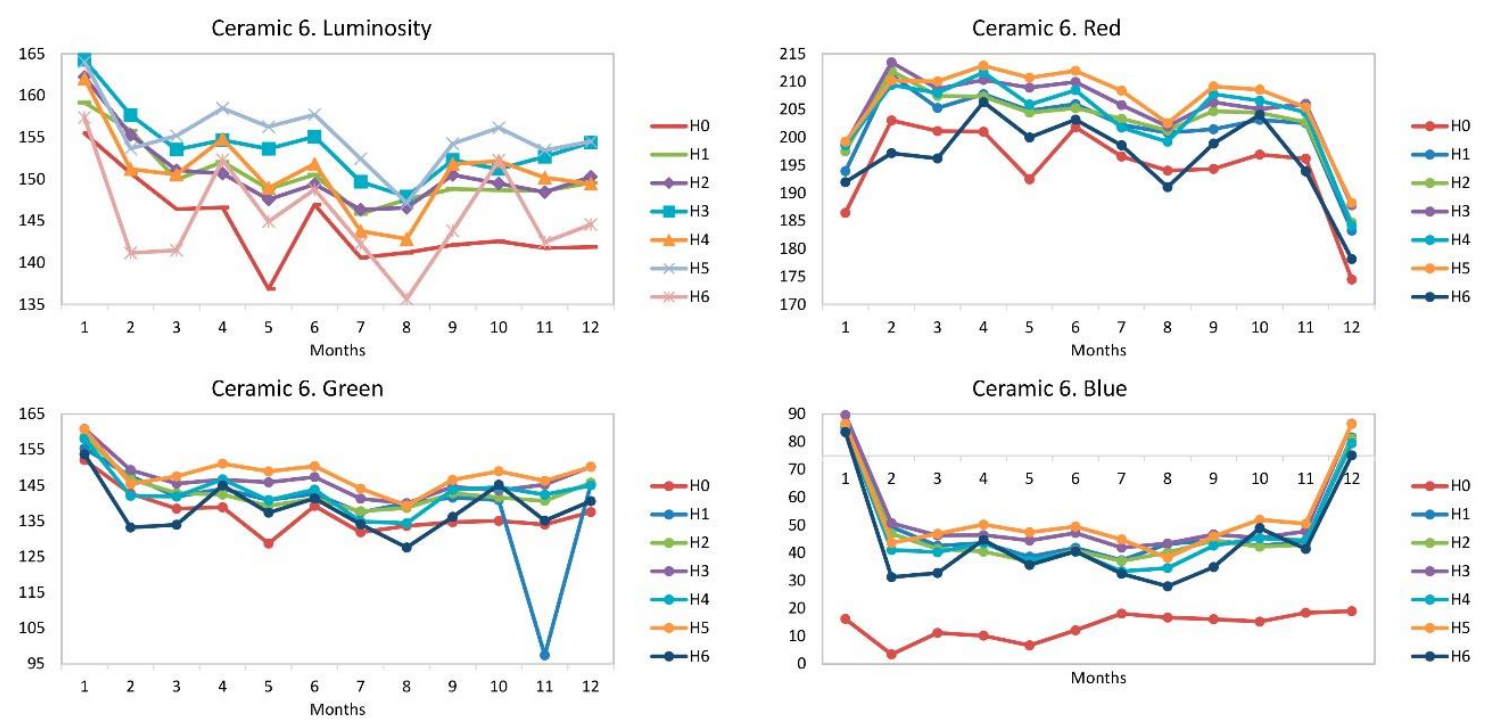

Discussion

It can be observed that in the six types of ceramic the colour of the untreated ceramic varies in each of the tested months, as well as the colour of the waterproofed ceramic with each one of the (theoretically colourless) products, being these chromatic variations irregular in the colour measurements. All the water repellents, when applied to the porous face ceramic produce colour variation in the base ceramic, being this either positive variation (increased histogram values) or negative (decreased histogram values). This chromatic variation depends on the initial colour of the ceramic and the composition of the applied water repellent (Coronado \& García, 2011), contrary to what other authors comment (García, Sánchez \& Frías, 1996) ) who claim that when water repellents or consolidating products are superficially applied, variations in the colour of the base treated material cannot be observed, but as time goes the material may vary its chromaticity depending on the applied product and solar radiation exposure. In a previous research (Coronado \& García, 2014, Coronado \& García, 2017) it was demonstrated that the colour variation in the ceramic depends only on the initial colour of ceramics at the time of application of the water repellent product.

It is observed that in the ceramic 1, the chromatic variation of aging ceramics with each product tends, in general, to the colour of the untreated ceramic. The luminosity and green, in month 12 , have very similar values to the untreated ceramics, slightly increasing values compared to month 1 . All the water repellent products cause loss of red, having in month 12 a positive variation compared to the untreated ceramic. The blue colour increases in month 12 in the treated ceramic with all products, presenting negative variation regarding the untreated ceramic.

In the ceramic 2, the colour variation in the month 12 presents more dispersed values, although there is an approach to the values of the aged ceramic with each product in comparison to the colour of the untreated ceramic. The luminosity and the red colour have the same tendency in the month 12 which is a general decrease in values, with positive variations in the ceramic untreated. In the green and blue, there is an approach of values to the untreated ceramics, except for the product $\mathrm{H} 3$, having, in the month 12 an overall increase in their values, positive and negative with respect to the variations in the untreated ceramic in the green colour, with all the negative variations in the colour blue.

The chromatic variation of ceramic 3 in the month 12 presents a general tendency with all the histogram values. In the month 12 all the values of treated ceramics tend to the colour of the untreated ceramics, with decreasing values in luminosity, red and green and an increase in blue colour. In all histogram values, there are positive variations in the waterproofed ceramic compared to the untreated ceramic.

The tendency in ceramics 4 is similar to that of the ceramic 3 observed in month 12 , the chromatic variations of the aging waterproofed ceramic tend to be like the colour in the untreated ceramic, presenting a decrease of values in luminosity, red and green and an increase in the blue colour. There are positive changes in luminosity, red and green, except for the product $\mathrm{H} 6$ in luminosity and in the green colour. In the blue colour exists a negative variation of the values of the treated ceramic compared to the base ceramic. 
It can be observed that in the ceramic 5, the chromatic variation of the waterproofed ceramic with each product tends to the colour of the untreated ceramic. The luminosity and red values, in month 12 , have decreased compared to month 1 , with the positive and negative variations in luminosity and positive in the red colour. All waterproofing products cause an increase of green and blue, having in month 12 a positive and negative variation if compared to the untreated ceramic in the green colour and negative in the blue colour.

Ceramic 6 shows, in all histogram values, a decrease of values at month 12 compared to the month 1, there is not a clear tendency that the colour variation of the treated ceramic with different products is the same to colour of ceramics without treating. In the four histogram values there are positive variations in relation to the untreated ceramics in month 12.

In the ceramics 1, 3, 4 and 5, the chromatic variation of the waterproofed ceramic with each product tends to the colour of the untreated ceramic, which may show that the applied product is deteriorating by exposure to ultraviolet light (Rivas, Silva \& Prieto, 1998).

In previous studies (Coronado, 2012; Coronado \& García, 2014; Coronado \& García, 2017) it is shown that there is a relation between the initial and final colour of the waterproofed ceramic at the time of its surface treatment, being possible to predict the colour obtained from the treated ceramic with a particular product. In other study on treatments of wood with varnishes (Rodríguez, 2012) it is shown that there is a correlation between the colour of natural wood, at the moment of varnishing it and after a natural aging of five years.

In order to verify if there is a relation between the initial colour (untreated) and final colour of the ceramic (waterproofed with each product) in its respective aging, is graphically represented in each of the tested months, the results obtained from the histogram values (luminosity, red, green and blue) of each waterproofed ceramic with each one of the products, placing on the horizontal axis $(X)$ values of the untreated ceramic and on the vertical axis $(Y)$ the values of the waterproofed ceramics, obtaining a cloud of points. It is calculated the equation of the trend line of the obtained cloud of points and the coefficient of determination $\mathrm{R}^{2}$, which indicates if there is a relation between tested variables ( $R^{2}$ values greater than 0.5 indicate that there is a relation between the represented variables). In Figure 7 , is shown an example of the obtained results of the red colour, of the waterproofed ceramics with the product $\mathrm{H} 2$ of silanes composition in the months 4 and 12 , where it can be seen the trend line, its equation and the value of $R^{2}$ coefficient.

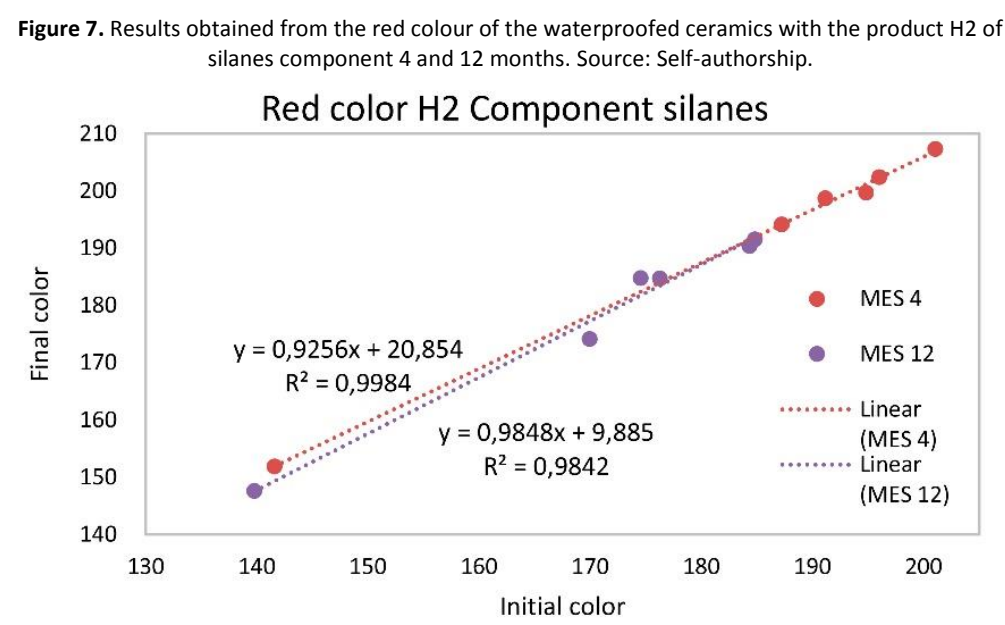

The results obtained from the equations of the trend lines and the respective coefficients $R^{2}$, are shown in Tables 2 to 3. Only the relation between the initial and final colours of month 1 and 12 are shown.

It is observed that in each month of completion of the test, exists a very strong relation between the values of the histogram of the initial and the final colour of the waterproofed ceramics with different products, because in all the cases there is an $\mathrm{R}^{2}$ coefficient greater than 0.9 . The relation between the initial and final colours of the waterproofed ceramic with each product is determined by the equations seen in the tables above. 
Table 2. Relation between the initial and final colour of the ceramic in month 1. Source: Self-authorship.

\begin{tabular}{|c|c|c|c|c|c|c|}
\hline \multirow{3}{*}{$\begin{array}{l}\text { Values of } \\
\text { histogram }\end{array}$} & \multicolumn{6}{|c|}{ Month 1: Relation between the initial and final colour of the ceramic } \\
\hline & \multicolumn{6}{|c|}{ Type of water repellent product } \\
\hline & \multicolumn{2}{|l|}{$\mathrm{H} 1$} & \multicolumn{2}{|l|}{$\mathrm{H} 2$} & \multicolumn{2}{|c|}{ H3 } \\
\hline Luminosity & $y=0.9632 x+$ & $\mathrm{R}^{2}=$ & $y=0.9754 x+$ & $R^{2}=$ & $y=1.0477 x+$ & $R^{2}=$ \\
\hline \multirow{3}{*}{ Red } & 8.346 & 0.9959 & 7.5716 & 0.9896 & 1.5887 & 0.9713 \\
\hline & $y=0.9117 x+$ & $R^{2}=$ & $y=0.9178 x+$ & $\mathrm{R}^{2}=$ & $y=1.1293 x-$ & $R^{2}=$ \\
\hline & 21.76 & 0.9883 & 22.839 & 0.9889 & 15.558 & 0.9886 \\
\hline \multirow[t]{2}{*}{ Green } & $y=0.9709 x+$ & $\mathrm{R}^{2}=$ & $y=0.9891 x+$ & $R^{2}=$ & $y=1.0102 x+$ & $\mathrm{R}^{2}=$ \\
\hline & 6.9423 & 0.9971 & 5.182 & 0.9903 & 6.8532 & 0.9634 \\
\hline \multirow[t]{3}{*}{ Blue } & $y=0.9339 x+$ & $\mathrm{R}^{2}=$ & $y=0.9483 x-$ & $\mathrm{R}^{2}=$ & $y=0.933 x+$ & $R^{2}=$ \\
\hline & 1.1508 & 0.9996 & 0.0149 & 0.9984 & 4.282 & 0.9903 \\
\hline & \multicolumn{2}{|l|}{$\mathrm{H} 4$} & \multicolumn{2}{|l|}{ H5 } & \multicolumn{2}{|c|}{$\mathrm{H} 6$} \\
\hline Luminosity & $y=1.0678 x-$ & $R^{2}=$ & $y=1.0986 x-$ & $R^{2}=$ & $y=1.0715 x-$ & $R^{2}=$ \\
\hline \multirow{3}{*}{ Red } & 6.3207 & 0.9869 & 10.566 & 0.9809 & 14.176 & 0.9499 \\
\hline & $y=1.0873 x-$ & $\mathrm{R}^{2}=$ & $y=1.0679 x-$ & $\mathrm{R}^{2}=$ & $y=0.9512 x+$ & $R^{2}=$ \\
\hline & 11.177 & 0.9745 & 7.0331 & 0.9652 & 9.3709 & 0.9454 \\
\hline \multirow[t]{2}{*}{ Green } & $y=1.0561 x-$ & $R^{2}=$ & $y=1.1159 x-$ & $\mathrm{R}^{2}=$ & $y=1.144 x-$ & $R^{2}=$ \\
\hline & 4.8646 & 0.9863 & 12.427 & 0.9849 & 24.457 & 0.9622 \\
\hline \multirow[t]{2}{*}{ Blue } & $y=0.9345 x-$ & $\mathrm{R}^{2}=$ & $y=0.9645 x-$ & $\mathrm{R}^{2}=$ & $y=0.9392 x-$ & $R^{2}=0.97$ \\
\hline & 0.4739 & 0.9952 & 2.0491 & 0.9914 & 4.617 & \\
\hline
\end{tabular}

Table 3. Relation between the initial and final colour of the ceramic in month 12 . Source: Self-authorship.

\begin{tabular}{|c|c|c|c|c|c|c|}
\hline \multirow{4}{*}{$\begin{array}{l}\text { Values of } \\
\text { histogram } \\
\text { Luminosity }\end{array}$} & \multicolumn{6}{|c|}{ Month 12: Relation between the initial and final colour of the ceramic } \\
\hline & \multicolumn{6}{|c|}{ Type of water repellent product } \\
\hline & \multicolumn{2}{|l|}{$\mathrm{H} 1$} & \multicolumn{2}{|l|}{$\mathrm{H} 2$} & \multicolumn{2}{|c|}{ H3 } \\
\hline & $y=1.1521 x-$ & $\mathrm{R}^{2}=$ & $y=1.1227 x-$ & $R^{2}=$ & $y=1.2541 x-$ & $R^{2}=$ \\
\hline & 15.388 & 0.9899 & 11.454 & 0.9885 & 23.729 & 0.9905 \\
\hline \multirow[t]{2}{*}{ Red } & $y=1.0102 x+$ & $\mathrm{R}^{2}=$ & $y=0.9848 x+$ & $R^{2}=$ & $y=1.2012 x-$ & $R^{2}=$ \\
\hline & 4.0309 & 0.9854 & 9.885 & 0.9842 & 25.17 & 0.9924 \\
\hline \multirow[t]{2}{*}{ Green } & $y=1.1722 x-$ & $\mathrm{R}^{2}=$ & $y=1.1438 x-$ & $\mathrm{R}^{2}=$ & $y=1.2248 x-$ & $\mathrm{R}^{2}=$ \\
\hline & 16.594 & 0.9936 & 13.274 & 0.9931 & 18.058 & 0.9832 \\
\hline \multirow[t]{3}{*}{ Blue } & $y=1.1597 x-$ & $\mathrm{R}^{2}=$ & $y=1.1612 x-$ & $\mathrm{R}^{2}=$ & $y=1.1768 x-$ & $\mathrm{R}^{2}=$ \\
\hline & 7.9095 & 0.9909 & 9.3211 & 0.9927 & 5.5554 & 0.9869 \\
\hline & \multicolumn{2}{|l|}{$\mathrm{H} 4$} & \multicolumn{2}{|l|}{ H5 } & \multicolumn{2}{|c|}{$\mathrm{H} 6$} \\
\hline Luminosity & $\begin{array}{c}\mathrm{y}=1.1799 \mathrm{x}- \\
18.831\end{array}$ & $\begin{array}{c}R^{2}= \\
0.9889\end{array}$ & $\begin{array}{c}y=1.2801 x- \\
29.604\end{array}$ & $\begin{array}{c}R^{2}= \\
0.9827\end{array}$ & $\begin{array}{c}y=1.0299 x- \\
2.9268\end{array}$ & $R^{2}=0.989$ \\
\hline Red & $\begin{array}{c}y=1.1494 x- \\
19.7\end{array}$ & $\begin{array}{c}R^{2}= \\
0.9895\end{array}$ & $\begin{array}{c}y=1.1395 x- \\
16.033\end{array}$ & $\begin{array}{c}R^{2}= \\
0.9781\end{array}$ & $\begin{array}{c}y=0.92 x+ \\
17.139\end{array}$ & $\begin{array}{c}R^{2}= \\
0.9736\end{array}$ \\
\hline Green & $y=1.1674 x-$ & $R^{2}=$ & $y=1.2923 x-$ & $\mathrm{R}^{2}=$ & $y=1.0667 x-$ & $\mathrm{R}^{2}=$ \\
\hline & 16.099 & 0.9899 & 28.981 & 0.9866 & 7.1779 & 0.9921 \\
\hline Blue & $\begin{array}{c}y=1.1052 x- \\
7.0417\end{array}$ & $\begin{array}{c}R^{2}= \\
0.9836\end{array}$ & $y=1.213 x-$ & $\begin{array}{c}R^{2}= \\
0905\end{array}$ & $y=1.0585 x-$ & $\begin{array}{c}R^{2}= \\
09848\end{array}$ \\
\hline
\end{tabular}

\section{Conclusions}

All water repellents superficially applied on the porous face ceramic produce colour variation in the process of aging during 12 months. During the month 12, there is a general tendency for all products to the loss of red and the gain of blue, changing its hue to the tones called "cold", increasing this effect in manual and extruded ceramics by the general increase in green.

A linear relation exists in each of the tested months, defined by the equations presented in the tables above, between the values of the histogram in the initial and final colours of the waterproofed ceramic with each of the applied products. Knowing the initial colour of a ceramic, one can predict the final colour, according to their RGB values, which will acquire in each of the months, depending on the composition of the water repellent product applied. 
In the heritage edifications constructed with treated porous ceramic which has been previously treated with water repellent, the original colour of ceramic could be found through linear relations exposed above, knowing two parameters: the composition of the product and the time it has aged.

AENOR-CEN (1984). UNE 67027-84. Ladrillos de arcilla cocida. Determinación de la absorción de agua. Asociación Española de Normalización (AENOR).

Akhan Baykan, N., Yilmaz, N., Kansun, G. (2010) Case study in effects of color spaces for mineral identification. Scientific Research and Essays, 5(11), 1243-1253. Retrieved from http://www.academicjournals.org/article/article1381226810_Baykan et al.pdf

Amoroso, G. G., \& Fassina, V. (1985). Stone Decay and Conservation: Atmospheric Pollution, Cleaning, Consolidation and Protecting. Bulletin of the Association for Preservation Technology, 17(3/4), 84. https://doi.org/10.2307/1494105

Coronado Martín, J. A. (2012). Influencia de los productos hidrofugantes en las propiedades superficiales de las cerámicas porosas utilizadas en cerramientos exteriores cara vista. Universidad Politécnica de Madrid.

Coronado Martín, J. A. \& García Santos, A. (2011). La influencia de los productos hidrofugantes en las modificaciones cromáticas del ladrillo cerámico. Materiales de construcción, 61(304), 597-611. https://doi.org/doi: http://dx.doi.org/10.3989/mc.2011.57810.

Coronado Martín, J. A. \& García Santos, A. (2014). Hidrofugante que menor variación cromática produce en la cerámica porosa cara vista. Boletín de la Sociedad Española de Cerámica y Vidrio. 54 (4): i-vi.

Coronado Martín, J. Á., \& García Santos, A. (2017). Parameters that influence the chromatic variation of porous face ceramic waterproofed with organosilicic products. Revista de La Construcción, 16(2), 295-306. https://doi.org/10.7764/RDLC.16.2.295

Cultrone, G., De la Torre, M. J., Sebastián, E., \& Cazalla, O. (2003). Evaluación de la durabilidad de ladrillos mediante técnicas destructivas (TD) y no-

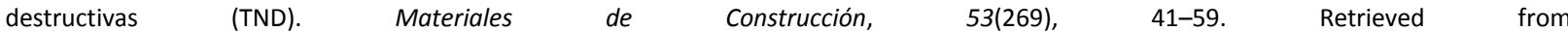
http://materconstrucc.revistas.csic.es/index.php/materconstrucc/article/viewFile/267/314

Esbert, R. M., Montoto, M., \& Ordaz, J. (1991). La piedra como material de construcción: Durabilidad, deterioro y conservación. Materiales de Construcción., 41(221), 61-73. Retrieved from http://materconstrucc.revistas.csic.es/index.php/materconstrucc/article /view /753/810.

Esbert, R. M., \& Sánchez, J. A. (1995). Hidrofugación de rocas carbonatadas porosas: Propiedades que controlan su eficacia. Materiales de Construcción, 45(237), 15-30. Retrieved from http://digital.csic.es/bitstream/10261/88513/1/12-12-2013.pdf

Fort Gonzalez, R. (2007). Ciencia, Tecnología y Sociedad para una conservación sostenible del patrimonio pétreo. San Sebastian de los Reyes: PérezMonserrat, E.M., Gómez-Heras, M. Álvarez de Buergo, M., Fort, R. Eds.

Fort Gonzalez, R. (2011). Tratamientos de conservación y restauración de geomateriales: tratamientos de consolidación e hidrofugación, pp.125-132. In: La conservación de los geomateriales utilizados en el patrimonio. Madrid: Universidad Complutense de Madrid.

García Pascua, N., Sánchez de Rojas, M. I. \& Frías, M. (1996). The important role of colour measurement in restoration Works. Use of consolidants and water repellents in sandstone. In 8th International Congress on deterioration of stone (pp. 1351-1361). Berlín: Josef Riederer.

García Pascua, N., Sánchez de Rojas, M. I. \& Frías, M. (1999). Medidas de color en diferentes materiales de construcción. La restauración en edificios de arenisca. Materiales de Construccion, 49(253), 29-45. Retrieved from digital.csic.es/bitstream/ 10261/35649/1/503.pdf

García Santos, A., \& Conci Rinaudo, M. (2005). Variación del color del soporte cerámico tratado con pintura antigraffiti. Materiales de Construcción, 55(278), 55-68. https://doi.org/10.3989/mc.2005.v55.i278.189

Kühnel, R.A. (2002). Driving forces of rock degradation. In: Protection and conservation of the cultural heritage of the Mediterranean cities. Swets \& Zeitlinger, Lisse, pp. 11-17.

Rivas, T., Silva, B., \& Prieto, B. (1998). Medida de la durabilidad de dos tratamientos de hidrofugación aplicados a rocas graniticas. Materiales de Construcción, 48(250), 5-14. Retrieved from http://materconstrucc.revistas.csic.es/index.php/materconstrucc/article/view/475/523

Rodríguez Rodríguez, A. (2012). Influencias de los barnices incoloros en las propiedades superficiales de las maderas de construcción. Universidad Politécnica de Madrid.

Sarabia Castelló, E., \& García Santos, A. (2015). Variation of the surface chromatic properties of exposed concrete façades treated with anti-graffiti products. Revista de la Construcción, 15(1), 51-60. Retrieved from http://rdlc.alerta.cl/index.php/rdlc/article/view/593/130

Wacker-Chemie, G. (1973). Procedimiento para hidrofugar superficies de materiales de construcción. Invention Patent. 